\title{
REGULATORY PROBLEMS OF DISASTER MANAGEMENT IN INDONESIA
}

\author{
Shanti Dwi Kartika \\ Research Centre of the General Secretariat of \\ the House of Representatives of the Republic of Indonesia \\ E-mail: sh4_dtika@yahoo.co.id
}

\begin{abstract}
Indonesia is a disaster-prone country. The state should protect the people and pay more attention to disaster management through legal instruments. To anticipate the disaster, the government has issued a legal policy in the form of Law Number 24 Year 2007 on Disaster Management. However, disaster management has not been effective. Therefore, it is important to understand about regulatory aspect of disaster management and legal issue in the implementation of disaster management. This study determined that the recent law of disaster management has been well improved following the previous law. In its implementation, there are still problems such as disharmony legislation in disaster management, overlapping authority and lack of inter-institutional coordination followed by overlapping authority, disoriented working procedures of disaster management and disaster management to uncontrolled funding. It's necessary harmonization of the legal system, institutional strengthening of the national disaster management agency and amendment of Disaster Management Act.
\end{abstract}

Keywords: disaster management, legal, regulatory

\begin{abstract}
Abstrak
Indonesia merupakan negara yang rawan bencana. Negara harus melindungi masyarakat dan memberikan perhatian lebih pada penanggulangan bencana melalui instrumen hukum. Untuk mengantisipasi bencana, pemerintah telah mengeluarkan kebijakan hukum dalam bentuk UU No. 24 Tahun 2007 tentang Penanggulangan Bencana. Namun, penanggulangan bencana belum efektif. Oleh karena itu, penting untuk memahami aspek regulasi dalam penanggulangan bencana dan permasalahan hukum dalam pelaksanaan penanggulangan bencana. Kajian ini menemukan bahwa hukum penanggulangan bencana yang baru telah lebih meningkat dari pada hukum penanggulangan bencana sebelumnya, terjadi beberapa permasalahan dalam implementasinya seperti diharmoni peraturan perundang-undangan, tumpang tindih kewenangan dan koordinasi antar-kelembagaan, tata kerja dan pendanaan dalam penanggulangan bencana. Atas dasar itu, perlu dilakukan harmonisasi dalam sistem hukum penanggulangan bencana, penguatan kelembagaan badan nasional penanggulangan bencana, dan perubahan UU Penanggulangan Bencana.
\end{abstract}

Kata kunci: penanggulangan bencana, hukum, peraturan.

\section{Introduction}

Indonesia is a disaster-prone country, because the characteristics of geological, geographical, and sociological put Indonesia as the area that are rich in disasters. ${ }^{1}$ Based on data from the National Agency for Disaster of the Republic of Indonesia, 2175 disasters that occurred until November 2016, such as floods (31.3\%), typhoons (20.8\%), landslides (17.3\%),

Iwan Subiyantoro, "Selayang Pandang Tentang Bencana”, Jurnal Dialog Penanggulangan Bencana, Vol.1 No.1, 2010, Jakarta: Badan Nasional Penanggulangan Bencana, page 44. fires (11.6\%), and drought (7.9\%). ${ }^{2}$ Basically, the disaster that often occurs is a manifestation of a combination between nature prone to physical system vulnerabilities that exist in Indonesian society, social system, culture, and politics. ${ }^{3}$ The disasters can have a big impact on the economy, social welfare, and politics of a country.

\footnotetext{
2 The National Agency for Disaster of Indonesia Republic, "Perbandingan Jumlah Kejadian Bencana per Jenis Bencana 1815-2016", available on the website http://dibi. bnpb.go.id/, accessed on January 9, 2017.

3 Christiana Yuni Kusmiati, "Menuju Perbaikan Manajemen Penanggulangan Bencana di Indonesia", Jurnal Administrasi Publik, Vol. 4 No. 2, October 2005, Bandung: Universitas Katolik Parahyangan.
} 
This indicates that the government has an important role in disaster management despite disaster management is the responsibility of all elements of society.

For that reason, the government has introduced policies and regulations related to the handling of the disaster. To provide a legal basis in disaster management, the government has formed and issued the enactment of Law No. 24 of 2007 on the Disaster Management (Disaster Management Act). This law has been in effect since enacted on April 26, 2007 and became the main source of law for the implementation of disaster management. There are several laws and regulations related to disaster management, whether that specifically regulate disaster management as stipulated by law Disaster Management Act and other legislation related to the disaster. However, disaster management has not been effective. One base issue of ineffectiveness of disaster management is the lack of policy and regulation at the national level regarding the handling of the disaster. ${ }^{4}$

Legislation relating to disasters, among others, the Disaster Management Act highly associated with legislation governing the use, management, and conservation of natural resources. According to Bayu Dwi Anggono, need harmonization between the Disaster Management Act with sectorial legislation because the law is closely related to other legislation governing natural resources so that there are overlaps and inconsistencies. ${ }^{5}$ This harmonization is required in order to avoid overlapping regulation and harmony between legal norms in regulations as the legal system in the national legal frameworks. ${ }^{6}$ Based on this theory, Hans Kelsen argues that legal norms tiered and layered in a

4 Heru Susetyo, "Urgensi Undang-Undang Penanggulangan Bencana di Indonesia," Lex Jurnalica Vol. 3 No. 1, April 2005, Jakarta: Universitas Esa Unggul, page 24.

5 Bayu Dwi Anggono, "Harmonisasi Peraturan Perundangundangan di Bidang Penanggulangan Bencana," Mimbar Hukum, Vol. 22 No. 2, Juni 2010, Yogyakarta: Universitas Gadjah Mada, page 373-390.

6 Sapto Budoyo, "Langkah Sistemik Harmonisasi Hukum dalam Pembentukan Peraturan Perundang-undangan", Civis, Vol. 4 No. 2, July 2014, Semarang: Universitas PGRI, page 608. hierarchy (arrangements), so the lower prevailing norms, based on norms derived and higher, whereas the higher prevailing norms, sourced, and based on the norms of higher again until a norm cannot be traced further and hypothetical and fictional is basic norm (grundnorm). ${ }^{7}$

The legal system is the result of the harmonization process of some elements and factors are processed by and uphold paradigms, principles, norms, and legal methods are certainly as previously agreed. Harmonization of this law shall refer to the legislation, the definition and scope, institutional integration, as well as codification and unification efforts. Disharmony in the Indonesia legal system is influenced by several factors. There are the differences between the various laws or regulations, conflict between the law by implementing regulations, difference between legislation with policies of government agencies, difference between legislation with jurisprudence and the court decision, policies of the central government agencies are conflicting, the difference between the policies of central and local government agencies, the difference between the provisions of the law with the formulation of a certain sense, and clash between the authority of government agencies because of the division of authority that is not systematic and clear.

Background illustrates that Indonesia has a high level of vulnerability to disasters and the government has issued a legal policy in the form of legislation. But in practice, the regulation of disaster management has not been effective. This study deals with legal issues of disaster management in Indonesia, which is: what the regulatory aspect of disaster management and what the legal issues in the implementation of disaster management. This study is intended to examine and analyse the regulatory aspects of disaster management. This study is expected to increase knowledge about disaster management and harmonization of regulations. Other than

Maria Farida Indrati S, 2007, Ilmu Perundang-undangan I: Jenis, Fungsi, dan Materi Muatan, Yogyakarta: Kanisius, pages $41-42$. 
that, this study is expected to be a reference for stakeholders, especially parliaments, governments, and national disaster management agency to making policies and regulations of the disaster management, including to revise the Disaster Management Act.

\section{Discussion}

\section{The Regulatory Aspect of Disaster Manage- ment}

The national political law should be able to encourage and fill all the elements in the national legal system. The national legal system is an integral unity in the development of the law, which consists of lawmaking, legal substance, legal executing, and law enforcement. ${ }^{8}$ It is means the dimensions of state administration, demanded optimal roles and responsibilities of the state to protect its people, either in the form of protection to life and the lives of the people including protection against natural disasters. ${ }^{9}$

In addition, the need for the presence of legal instruments in disaster management is influenced by the momentum of natural disasters period 1989 to 2007 and human factors such as vertical conflict that occurred in some areas. The disasters often occur in Indonesia affected by the hazard pose risks and social conflict. This is the legal political factors that affect the establishment of the political of law of disaster management.

The occurrence of disasters and the need for a comprehensive legal instrument of disaster is influenced by the condition of Indonesia which at the time was not yet has a basic policy in the form of legislation in a coherent and comprehensive set of disaster management and policy framework that is no longer relevant in the context of democracy and an autonomy. This occur has been aware of the Indonesian people will need to have a comprehensive dis-

8 Riri Nazriyah, "Peranan Cita Hukum dalam Pembentukan Hukum Nasional," Jurnal Hukum lus Quia lustum, No. 20 Vol. 9, June 2002, Yogyakarta: Universitas Islam Indonesia, page 137.

9 Shanti Dwi Kartika, "Politik Hukum Penanggulangan Bencana,” Jurnal Kajian, Vol. 20 No. 4, December 2015, Jakarta: Pusat Pengkajian Pengolahan Data dan Informasi, Sekretariat Jenderal DPR RI, page 335 aster management system nationally or disaster management system. ${ }^{10}$ Other than that, the disaster management system still materially sectorial, fragmented, and focused on the emergency response before the enactment of the Disaster Management Act. The regulations of disaster management have indication of conflict because of overlapping arrangements, institutional, and authority resulting in inconsistencies and multiple interpretations in the legislation. Therefore, the normative disaster management should be regulated.

To meet legal requirements and improve disaster response pattern, the Government and the House of Representatives of the Indonesia Republic have enacted Disaster Management Act on April 26, 2007 to be the legal basis for disaster management in Indonesia. The Disaster Management Act is a decision between the Parliament and the President as the legal policies of the results of the political process for disaster management in Indonesia. Disaster Management Act essentially regulates the implementation of disaster management, the foundation of norms and values, institutions, distribution of authority, and law enforcement. After the enacted Disaster Management Act, disaster management has ad new dimension in the pattern and system of disaster management in Indonesia. There is a change in the system of disaster management in Indonesia after enacted Disaster Management Act as shown at Table 1.

Table 1. Comparative Perspectives of Old and New System of Disaster management

\begin{tabular}{|l|l|l|}
\hline & Old System & \multicolumn{1}{|c|}{ New System } \\
\hline Legal basic & Sectoral & $\begin{array}{l}\text { Generally appli- } \\
\text { cable and binding } \\
\text { on all depart- } \\
\text { ments, public and } \\
\text { non-governmen- } \\
\text { tal organizations }\end{array}$ \\
\hline Paradigm & $\begin{array}{l}\text { Emergency } \\
\text { response }\end{array}$ & $\begin{array}{l}\text { Mitigation, emer- } \\
\text { gency response, } \\
\text { rehabilitation and } \\
\text { reconstruction }\end{array}$ \\
\hline Institute & $\begin{array}{l}\text { Disaster man- } \\
\text { agement coor- } \\
\text { dination body }\end{array}$ & $\begin{array}{l}\text { National Board } \\
\text { for Disaster Ma- } \\
\text { nagement BNPB), }\end{array}$ \\
\hline
\end{tabular}

10 Syamsul Maarif, "Bencana dan Penanggulangannya dari Aspek Sosiologis," Jurnal Dialog Penanggulangan Bencana, Vol. 1 No. 1, Tahun 2010, Jakarta: Badan Nasional Penanggulangan Bencana, page 4. 


\begin{tabular}{|c|c|c|}
\hline & Old System & New System \\
\hline & $\begin{array}{l}\text { (Bakornas PB), } \\
\text { implementing } \\
\text { coordination } \\
\text { unit (Satkor- } \\
\text { lak), and im- } \\
\text { plementing } \\
\text { units (Satlak) }\end{array}$ & $\begin{array}{l}\text { Provincial Disas- } \\
\text { ter Management } \\
\text { Agency (BPBD } \\
\text { Provinsi), disaster } \\
\text { response agencies } \\
\text { of district/city } \\
\text { (BPBD Kab/ Kota) }\end{array}$ \\
\hline $\begin{array}{l}\text { Role of civil } \\
\text { society }\end{array}$ & Limited & $\begin{array}{l}\text { Actively involve } \\
\text { community }\end{array}$ \\
\hline $\begin{array}{l}\text { Division of } \\
\text { responsibili- } \\
\text { ties }\end{array}$ & $\begin{array}{ll}\text { Most of the } \\
\text { central go- } \\
\text { vernment }\end{array}$ & $\begin{array}{l}\text { Responsibility of } \\
\text { the central } \\
\text { gover-nment, } \\
\text { provincial and } \\
\text { district }\end{array}$ \\
\hline $\begin{array}{l}\text { Development } \\
\text { Planning }\end{array}$ & $\begin{array}{l}\text { Not to be part } \\
\text { of develop- } \\
\text { ment planning } \\
\text { aspects }\end{array}$ & $\begin{array}{l}\text { National Action } \\
\text { Plan for Disaster } \\
\text { Risk Reduction } \\
\text { a. Disaster ma- } \\
\text { nagement } \\
\text { plan } \\
\text { b. Regional Ac- } \\
\text { tion Plan for } \\
\text { Disaster Risk } \\
\text { Reduction }\end{array}$ \\
\hline $\begin{array}{l}\text { Mitigation } \\
\text { approach }\end{array}$ & Susceptibility & $\begin{array}{l}\text { Risk analysis } \\
\text { (combining vul- } \\
\text { nerability and ca- } \\
\text { pacity) }\end{array}$ \\
\hline \multirow{2}{*}{$\begin{array}{l}\text { Forum coope- } \\
\text { ration among } \\
\text { stake-holders }\end{array}$} & \multirow[t]{2}{*}{ Not available } & $\begin{array}{l}\text { National Plat- } \\
\text { form }\end{array}$ \\
\hline & & $\begin{array}{l}\text { Provincial Plat- } \\
\text { form }\end{array}$ \\
\hline $\begin{array}{l}\text { Budget allo- } \\
\text { cation }\end{array}$ & $\begin{array}{l}\text { Responsibility } \\
\text { of the central } \\
\text { government }\end{array}$ & $\begin{array}{l}\text { Depending on the } \\
\text { level of disaster }\end{array}$ \\
\hline $\begin{array}{l}\text { Guidelines } \\
\text { for Disaster } \\
\text { Management }\end{array}$ & $\begin{array}{l}\text { Fragmented } \\
\text { and sectorial }\end{array}$ & $\begin{array}{l}\text { Referring to the } \\
\text { guidelines made } \\
\text { by BNPB and BP- } \\
\text { BD }\end{array}$ \\
\hline $\begin{array}{l}\text { With Spatial } \\
\text { Linkage }\end{array}$ & $\begin{array}{l}\text { Not to be as- } \\
\text { pects }\end{array}$ & $\begin{array}{l}\text { Disaster aspect } \\
\text { should be consi- } \\
\text { dered in the pre- } \\
\text { paration of spa- } \\
\text { tial }\end{array}$ \\
\hline
\end{tabular}

Table 1 shows that disaster management in Indonesia experiencing a paradigm shift since the enactment of the Disaster Management Act. Disaster management is no longer on all aspects of emergency response, but also emphasizes all aspects of disaster management which includes the pre-disaster mitigation, emergency response in times of disaster, and post-disaster rehabilitation and reconstruction. The disaster management involving all stakeholders from the natio- nal and regional level, and involves the active participation of society. The establishment of the Disaster Management Act is influenced by the changes that occur in the community related to the disaster emergency response be seen from risk management, protection of government into protection as human rights for the people, and disaster management as the responsibility of the state be run disaster management as a shared responsibility of all elements of the nation. It expands disaster management to public space by changing all aspects of policy, institutional, coordination, and mechanisms that give more space for public participation, non-governmental organizations, businesses, and the international community.

The Disaster Management Act mandates a paradigm shift in disaster management in Indonesia, namely of emergency response turns into risk reduction. This means that the paradigm shift from emergency response into disaster risk reduction with risk management, then the elements of the emergency response phase as predisaster need to be prepared in an integrated manner with an emphasis on prevention and preparedness elements. ${ }^{11}$ Disaster Management Act comprehensively identify the disaster as an event or series of events that threaten and disrupt the lives and livelihoods caused by three factors, namely natural factors, non-natural factors, and the human factor which is then referred to as a social disaster. By regulation, the disaster caused by these three factors are legislation disaster field, aspects of legislation zoning and environmental, legislation decentralization and specificity, sectorial legislation, and legislation supporting of disaster mitigation. There are based on The Constitution of 1945 which is the highest hierarchy of legislation of the Republic of Indonesia. On this basis, the fifth legal arena for this disaster spread on some legislation at the level of legislation. For

\footnotetext{
1 Shandra Lisya Wandasari, "Sinkronisasi Peraturan Perundang-undangan dalam mewujudkan Pengurangan Risiko Bencana," Unnes Law Journal, Vol. 2 No. 2, 2013, Semarang: Faculty of Law Universitas Negeri Semarang, page 138.
} 
it, is necessary to harmonize and changes to Disaster Management Act which is based on the dynamics of legal norms.

\section{The Legal Issues in the Implementation of Dis- aster Management}

There are several issues arising from the disaster, among other disasters are difficult to predict, the equipment used to secure and evacuate disaster victims is still limited and the lack of coordination between the central government and local governments in disaster management is not maximized and optimized, disaster management is still using the paradigm which is partial, the government has not properly carry out its function in the protection of victims. Besides set in the Disaster Management Act and its implementing regulations, the disaster is the substance that is tangent to the setting in some legislation. Based on the legal aspect of the Disaster Management Act, this act serve as a legal basic that is lex generalist and comprehensive for disaster management with all regulatory and policy implementation. However, the law is dynamic following the developments and changes, including in terms of disaster, so there would be possible legal issues in the implementation of the Disaster Management Act.

Disaster Management Act is classifying disaster into three groups, namely natural disasters, man-made disasters, and social disaster. Disaster Management Act gives a new dimension to disaster management in Indonesia, which was followed by the enactment of legislation that implementation of Government Regulation Number 21 Year 2008 on the Implementation of Disaster Management, Government Regulation Number 22 Year 2008 on Financing and Management of Disaster Assistance, Government Regulation Number 23 Year 2008 on the Participation of International Institutions and Foreign NonGovernment Institutions in Disaster Management, and Presidential Decree Number 8 Year 2008 on the National Disaster Management Agency. Besides set in the Disaster Management Act and its implementing regulations, the disaster is the substance that is tangent to the setting in some legislation. The constraints faced in the implementation of the Disaster Management Act, namely: first, before the enactment of the Disaster Management Act has no legisla-tion governing disaster relief efforts in related sectors which have consequences sectorial responsibilities; and second, found indications of legislation both at the centre and in areas relating to disaster relief efforts are still showing symptoms overlap, conflict, inconsistency, and multiple interpretations.

In its implementation, there are still problems such as disharmony legislation in disaster management, overlapping authority and lack of inter-institutional coordination, and working procedures of disaster management and disaster management funding. The first problem of the implementation of disaster management is disharmony regulation in disaster management. This regulatory harmonization needs to be done, because it has elements of Disaster Management Act disorders with some sectorial laws and authority vested in them, such as the Law Number 27 Year 2007, the Law Number 7 Year 2012, the Law Number 26 Year 2007, and the Law Number 31 Year 2009. It means the substance of the legislation relating to disaster management, such as natural resources, the authority of government, institutional, financial, and environmental.

Against this legal issues need to be harmonized by the dynamics of legal norms. This harmonization is necessary for the implementation of the Disaster Management Act has been linked with several other legislations although not specifically regulates disaster management. Other than that, regulation of disaster management is necessary for the harmonization of the laws of disaster management have an element of disharmony with some sectoral laws, includeing the authority in it. Harmonization is needed, because the Indonesian legal system is plural can trigger disharmony legislation.

Harmonization undertaken should refer to the legislation, the definition and scope, institutional coherence, the efforts of codification, and unification. This harmonization can't be separated from rechtidee and staat fundamen- 
tal norm, for later study the vertical and horizontal synchronization as a form of harmonization. Synchronization is carried out in accordance with the theory of the hierarchy of legal norms (stufenbau theory). A legal norm is sourced and based on the norm across it and down into the rule below it. A legal norm has a validity period depends on the norms laws that are in it. The positive law is arranged in a logical hierarchy pyramid. The hierarchy of legal norms articulated in the hierarchy of legislation in Indonesia as stipulated in the Law Number 12 Year 2011. Hierarchy of legislation puts NRI Constitution of 1945 as the highest legislation in Indonesia. On that basis, the legislation in the field of disaster management refers to the NRI Constitution of 1945.

Implementation of disaster management ultimately implemented by government regulations and ministerial level decisions and institutions. In the execution of the respective ministries and agencies make their own rules, as derived above legislation on it. These conditions gave rise to potential inconsistencies in the implementation of disaster management. However, disharmony legislation in disaster management, it makes overlapping authority and lack of inter-institutional coordination of ministries/ agencies that run the disaster management authority as has been derived from sectorial laws as their roles, responsibilities, and functions of the sector.

This means the problem arises when the alignment and coordination across sectors to realize the disaster. The National Agency for Disaster of Indonesian Republic difficulty carrying out the mandate to coordinate ministries and agencies, when traced it seems originated from Presidential Decree Number 8 Year 2008 on the Establishment the National Agency for Disaster of Indonesian Republic. The institutionnal problems continue with The Presence of Presidential Decree Number 4 Year 2012 on Disaster Management Flood and Landslide (Instruction 4/2012). Substance Instruction 4/2012 basically reaffirms coordinates the functions of ministries and agencies should do the National Agency for Disaster of Indonesian Republic. The presence of this Instruction may be interpreted as a statement of inability to coordinate all components of disaster, able to coordinate and willing coordinate.

This misalignment results in a clash of authority and lack of institutional coordination is responsible for dealing with disasters. This is due to sectoral laws granting authority to the institutions to deal with the disaster, while the National Disaster Management Agency is mandated to coordinate the ministries, agencies, and local governments in disaster management. This has an impact on the working procedures and disaster relief funding, because ministries, agencies, and local governments will have the working procedures of disaster management along with funding.

The other regulatory problems of disaster management are working procedures and funding which of disaster management are related to Law Number 32 Year 2004 on Regional Government and Law Number 33 Year 2004 on Fiscal Balance between the Government and the Local Government. Both of regulation is not set mandate for local government in the disaster management, even in Law Number 23 Year 2014 on Regional Government also does not give authority to the local government in disaster management. This resulted in the disaster management has not become the principal mandate funding for activities disaster management becomes stepchild in the financial balance of development. Disaster management funding in areas not included in the main priorities. The same thing affairs division between central and local government in the implementation of the disaster management is often considered to be unclear. Besides these laws, Government Regulation Number 22 Year 2008 on Disaster Management Funding and Government Regulation Number 38 Year 2007 on Government Affairs Division of the Provincial Government and local government, district/ city, or between the Provincial Government and the Government of Regency/ 
City are still not significant. One of the legal instruments used are Government Regulations Number 44 Year 2012 on the Emergency Fund. Regulation needs to accommodate the use of emergency funds-practice emergency response led to the status of emergency preparedness and emergency transition, considering the implications there.

This means that the disharmony in disaster when viewed from factors causing disharmony by LM Lapian Gandhi. The differences between the various laws and regulations, the difference between law enforcement regulations, and the clash of authority from stakeholders because of the division of authority that is not systematic and clear are pull factors that cause the lack of disaster management regulations. Other than that, a prerequisite for effective disaster management that is the direction and political commitment is reflected in the policy constitutional, statutory, regulatory regions, executive development policy, as well as sectorial elements. This means that the lack of disaster management regulation influenced by legal substance, legal structure, and legal culture.

Without a clear policy, would not be the norm that can be used to determine the goals and motivate political-bureaucratic behaviour to achieve it. Therefore, the legal policy of the disaster can be assessed and evaluated on policies related to the disaster. Disaster Management Act enacted in hopes of becoming a strong legal foundation in disaster management, overcoming the weakness of inter-sector coordination, encourage synergy of the various parties in disaster management, disaster management and to realize a more systematic, integrated, and coordination. This means that the Disaster Management Act can't see as the imperative norm or necessity (das sollen) but it's should be a subsystem which das sein. ${ }^{12}$ This act is determined by politic, in the formulation of the legal

12 Martha Pigome, "Implementasi Prinsip Demokrasi dan Nomokrasi dalam Struktur Ketatanegaraan RI Pasca Amandemen UUD 1945”, Jurnal Dinamika Hukum, Vol. 11 No. 2, May 2011, Purwokerto: Faculty of Law Universitas Jenderal Soedirman, page 339. substance as well as in the implementation and enforcement.

But it's in implementation of disaster management has regulatory problems. Problem solving from the legal issue in the implementation of disaster management is needed to be harmonized by the dynamics of legal norms in accordance with the theory of the hierarchy of legal norms. It means to solve these problems, necessary harmonization of the legal system and the legislation for the creation of a system that is more comprehensive disaster management, compile and collect the legislation that has been there for more convenient reference in disaster management, and create a database of legislation.

It is also necessary for the institutional strengthening of the national disaster management agency and amendments of Disaster Management Act. It needs to be done in the context of risk management based disaster management. For that, the national disaster management agency should be given to strengthening the institutional form: first, strengthening the role of the national disaster management agency in cooperation and coordination with the ministries/ agencies and local governments in the implementation of disaster management, secondly, strengthening the function of coordinating, implementing, and command, and thirdly, strengthening capacity through availability of human resources, budget, facilities, and infrastructure as a supporting system in disaster management. In addition, there should be also the structuring and setting the working relationship between the national disaster management agencies with the regional disaster management agency to strengthen the capacity of national disaster management operations. To harmonize of disaster management, the government can do to enforcement the regulatory and strengthen the institutional. These efforts can be done by using a harmonized approach for legal codifica-tion and unification of disaster management, cross-sectoral approach in organizing and carry-ing out disaster relief, as well as community participation approach 


\section{Conclusion}

This study found that the recent law of disaster management has been well improved than that the previous law. However, in its implementation, there are still problems such as disharmony legislation in disaster management, overlapping authority and lack of inter-institutional coordination, and working procedures of disaster management and disaster management funding.

\section{Suggestion}

To solve these legal issues, necessary harmonization of the legal system and the legislation for the creation of a system that is more comprehensive disaster management, compile and collect the legislation that has been there for more convenient reference in disaster management, and create a database of legislation. It is also necessary for the institutional strengthening of the national disaster management agency and amendment of Disaster Management Act.

\section{Bibliografi:}

Anggono, Bayu Dwi. "Harmonisasi Peraturan Perundang-undangan di Bidang Penanggulangan Bencana." Mimbar Hukum. Vol. 22 No. 2. June 2010. Yogyakarta: Faculty of Law Universitas Gadjah Mada;

Budoyo, Sapto. "Langkah Sistemik Harmonisasi Hukum dalam Pembentukan Peraturan Perundang-undangan." Civis. Vol. 4 No. 2. July 2014. Semarang: Universitas PGRI;

Kartika, Shanti Dwi. “Politik Hukum Penanggulangan Bencana." Kajian. Vol. 20 No. 4. December 2015. Jakarta: Pusat Pengkajian Pengolahan Data dan Informasi. Sekretariat Jenderal DPR RI;

Kusmiati, Christiana Yuni. "Menuju Perbaikan Manajemen Penanggulangan Bencana di Indonesia". Jurnal Administrasi Publik. Vol. 4 No. 2. October 2005. Bandung: Universitas Katolik Parahyangan;

Nazriyah, Riri. "Peranan Cita Hukum dalam Pembentukan Hukum Nasional." Jurnal Hukum lus Quia lustum. No. 20 Vol. 9. Ju- ne 2002. Yogyakarta: Faculty of Law Universitas Islam Indonesia;

Maarif, Syamsul. "Bencana dan Penanggulangannya dari Aspek Sosiologis." Jurnal Dialog Penanggulangan Bencana. Vol. 1 No. 1. 2010. Jakarta: Badan Nasional Penanggulangan Bencana;

Pigome, Martha. “Implementasi Prinsip Demokrasi dan Nomokrasi dalam Struktur Ketatanegaraan RI Pasca Amandemen UUD 1945". Jurnal Dinamika Hukum. Vol. 11 No. 2. May 2011. Purwokerto: Faculty of Law Universitas Jenderal Soedirman;

S, Maria Farida Indrati. 2007. Ilmu Perundangundangan I: Jenis. Fungsi. dan Materi Muatan. Yogyakarta: Kanisius;

Subiyantoro, Iwan. "Selayang Pandang Tentang Bencana." Jurnal Dialog Penanggulangan Bencana. Vol. 1 No. 1. 2010. Jakarta: Badan Nasional Penanggulangan Bencana;

Susetyo, Heru. "Urgensi Undang-Undang Penanggulangan Bencana di Indonesia." Lex Jurnalica Vol. 3 No. 1. April 2005. Jakarta: Faculty of Law Universitas Esa Unggul;

The National Agency for Disaster of Indonesia Republic. "Perbandingan Jumlah Kejadian Bencana per Jenis Bencana 18152016". available on the website http:// dibi.bnpb.go.id/. accessed Jan 9. 2017;

Wandasari, Shandra Lisya. "Sinkronisasi Peraturan Perundang-undangan dalam mewujudkan Pengurangan Risiko Bencana." Unnes Law Journal. Vol. 2 No. 2. 2013. Semarang: Faculty of Law Universitas Negeri Semarang. 